Information for citation:

Amangeldy, A. A. (2021) Digital Technologies Incorporation into Legislation of the Republic of Kazakhstan. European and Asian Law Review. 4 (1), 52-60. DOI: 10.34076/27821668_2021_4_1_52.

UDC 347.1/9/34.08

BISAC LAW 011000

DOI: 10.34076/27821668_2021_4_1_52

Research article

\title{
DIGITAL TECHNOLOGIES INCORPORATION INTO LEGISLATION OF THE REPUBLIC OF KAZAKHSTAN
}

\author{
AIZHAN A. AMANGELDY \\ Euroasian Law Academy of D. A. Kunaev \\ ORCID ID: 0000-0001-5971-1219
}

The incorporation of digital technologies at the level of the legislation of the Republic of Kazakhstan has taken place since 2003. Numerous legislative acts and amendments to them in pursuit of digital technologies development have been adopted. The article analyses the changes in the civil legislation, civil procedural and labour legislation of the Republic of Kazakhstan, regulating the turnover and use of digital technologies. In the accordance with the legislation of the Republic of Kazakhstan the author considers new concepts in the sphere of digital technologies, including digital assets and digital rights. Most of legal scientists in the field of civil law conclude that digital assets, digital rights are not by their nature a new type of property, property right, and the digital form represents only a way of fixing the property. Moreover, in response to legal proceedings digitalization access to justice had made a significant step towards development, there are much more positive aspects in this process: avoiding document exchange, saving time, simplified search for court cases, notifying the parties involved using various communication methods, which makes it possible to speed up the communication process, unlike postal service providers. Nevertheless, it is highly important to ensure legal regulation in the conditions of global digitalization in order to protect rights of a person to information and confidentiality.

Key words: digital asset, digital technologies, electronic document exchange, electronic digital signature, e-judicial proceedings, electronic evidence

\section{Introduction}

The incorporation of digital technologies started with emergence of the Internet and rapid development of information technologies, widespread use of computer programs. In Kazakhstan the transition to digital technologies at the legislative level has taken place gradually since 2003.

\section{Materials and methods}

When drafting the article, the author used the following general scientific and special research methods: analysis, synthesis, formal legal and comparative legal methods.

\section{Results}

The results of this study are specified in the conclusions of this article.

\section{Discussion}

The first introduction of the digital format at the level of the legislation of the Republic of Kazakhstan was associated with the adoption of the Law of the Republic of Kazakhstan dated January 7, 2003 
No. 370-II 'On Electronic Documentation and Electronic Digital Signature', which specified such terms as 'electronic document exchange', 'electronic archive', 'electronic digital signature' (hereinafter - EDS), 'electronic document' ${ }^{1}$. It cannot be said that after that the electronic digital signature was widely available, only in certain branches, for example, in the interbank settlement system, on the website of the electronic Government E-gov'. Many questions arose about the use of EDS itself. In connection with the adoption of the Law of the Republic of Kazakhstan 'On Electronic Documentation and Electronic Digital Signature' there was the Law of the Republic of Kazakhstan 'On Amendments to a Number of Legislative Acts of the Republic of Kazakhstan in Connection with Electronic Documentation, Electronic Digital Signature and Information Technology' dated January 7, 2003 No. 372-II ZRK (hereinafter - the RK Law dated January 7,2003 ) adopted, which made amendments to the Civil Code of the Republic of Kazakhstan in regard of use of the electronic digital signature when concluding deals as per paragraph 2 of Article 152 of the Civil Code of the Republic of Kazakhstan ${ }^{3}$. The RK Law dated January 7, 2003 expanded the list of grounds according to which the deal is equated to the written form of the deal, namely, according to paragraph 3 of Article 152 of the Civil Code of the Republic of Kazakhstan, in case of exchange the electronic documents, defining the subjects and the content of their will expression ${ }^{4}$.

The Law of the Republic of Kazakhstan 'On Amendments to a Number of Legislative Acts of the Republic of Kazakhstan in Connection with Information Technology' dated November 24, 2015 No. 419V ZRK (hereinafter - the RK Law dated November 24, 2015) added Article 152 of the Civil Code of the Republic of Kazakhstan with paragraph 1-1 with the following content: '1-1. The written form of the deal is made on a hard copy or in the electronic form's. Thus, deals in the electronic form were included into civil-law transactions, which are attributed by the legislature to the written form of the deal. Such deals have become quite widespread in the sphere of public procurement, contracts for procurement of goods, works and services were concluded through electronic contracts signed by the EDS.

The RK Law dated November 24, 2015 expanded the list of grounds according to which the deal is equated to the written form of the deal, namely, according to paragraph 3 of Article 152 of the Civil Code of the Republic of Kazakhstan, in case of not only exchange of electronic documents, but also of electronic messages, defining the subjects and the content of their will expression.

The RK Law dated November 24, 2015 introduced the term of the electronic offer, namely into paragraph 2 of Article 397 of the Civil Code of the Republic of Kazakhstan. According to this paragraph, when the written or electronic offer does not contain specified period for acceptance, the contract is considered concluded if the acceptance is received by the person who sent the offer before the end of the period established by law, and if this period is not established - within the time necessary for this.

However, at present, the changes determined by introduction of digital technologies in many public and state-related processes are included into the main legislative act regulating civil-law transactions - the Civil Code of the Republic of Kazakhstan. And it should be noted that the norms introduced into the Civil Code of the Republic of Kazakhstan are not welcomed by the civil science community.

To M. K. Suleymenov's (2021) opinion, the attempts to amend the Civil Code have turned out to be not very successful. First of all, this concerns the concept of digital rights. But the introduction of this concept into the Civil Code of the Russian Federation will not do much harm so far, since its implementation into the real life is attributed to the future legislative regulation. Although there remains the theoretical problem of the relationship between digital rights and property rights, which is solved, in my opinion, is not quite correct in the Civil Code of the Russian Federation. As for the attempt to resolve this issue in the draft law of the Republic of Kazakhstan on digital technologies, the introduction of the concept of 'digital assets',

\footnotetext{
${ }^{1}$ Law of the Republic of Kazakhstan of January 7, 2003 No. 370-II 'On Electronic Documentation and Electronic Digital Signature'.

${ }^{2}$ Available from: https://egov.kz [Accessed: 01 May 2021].

${ }^{3}$ Civil Code of the Republic of Kazakhstan of December 27, 1994(General Part). Available from: https://online.zakon.kz/ Document/?doc_id=1006061 [Accessed: 01 May 2021].

${ }^{4}$ Law of the Republic of Kazakhstan of January 7, 2003 No. 372-II 'On Amendments to a Number of Legislative Acts of the Republic of Kazakhstan in Connection with Electronic Documentation, Electronic Digital Signature and Information Technology'. IS 'Paragraph'.

${ }^{5}$ Law of the Republic of Kazakhstan of November 24, 2015 No. 419-V ZRK 'On Amendments to a Number of Legislative Acts of the Republic of Kazakhstan in Connection with Information Technology'. IS 'Paragraph'.
} 
especially in this form, seems completely unacceptable. The best solution is to leave the Civil Code of the Republic of Kazakhstan aside so far, until we will be ready with the theoretical positions. The digital right is not an independent property right along with liability and other rights, but a way of securing property rights. If we enshrine this concept in the Civil Code, then, in my opinion, it should be stated in this way. And it is difficult to disagree with this point of view, especially that there is a certain confusion in the norms of the legislation of the Republic of Kazakhstan.

Law of the Republic of Kazakhstan 'On Amendments to a Number of Legislative Acts of the Republic of Kazakhstan in Connection with Regulation of Digital Technologies' dated June 25, 2020 No. 347 VI ZRK added paragraph 2 of Article 397 of the Civil Code of the Republic of Kazakhstan with the term 'digital assets' in the description of the property composition, and Article 116 thereof is added with paragraph 3-1 with the following content: '3-1. The concept and types of digital assets, as well as features of the turnover of digital assets are determined by the legislation of the Republic of Kazakhstan, acts produced by International Financial Centre 'Astana' ${ }^{6}$. Thus, the digital asset being a part of the property becomes freely transferable. Although the Law of the Republic of Kazakhstan 'On Information Technology Development' regulates the concept of the digital asset not as a part of property, but as a form of property, namely as the electronic digital form of property, which of course is more like the truth. Since in this view only the form of property is digital.

The Law of the Republic of Kazakhstan 'On Information Technology Development' dated November 24, 2015 No. 418-V ZRK ${ }^{7}$ makes provisions with regard to the following definitions:

blockchain - an information and communication technology that ensures the immutability of information in a distributed data platform based on a chain of interconnected data blocks, specified algorithms for confirming the integrity and encryption facilities,

digital asset - a property created in the electronic digital form using cryptography and computer calculations, being not a financial instrument, as well as an electronic digital form of certification of property rights,

digital mining - a process of carrying out computational operations using computer, energy capacities in accordance with the given encryption and data processing algorithms, ensuring the confirmation of the integrity of data blocks in objects of informatization by means of the blockchain,

digital token - a type of a digital asset, representing digital facilities for accounting, exchange and certification of property rights,

'electronic akimat' - a system of information interaction of local executive authorities with state bodies and individuals/legal entities, based on automation and optimization of the state functions, designed to provide services in electronic form; a part of the 'electronic government',

'electronic government' - a system of information interaction between state bodies, between state bodies and individuals/legal entities, based on automation and optimization of the state functions, designed to provide services in electronic form,

electronic industry - a branch of industry that includes the design, assembly, testing and manufacturing of devices such as computers, computer peripheral equipment, communication facilities, electronic devices for consumers, measuring, testing and aviation, irradiation-resistant components for space, electro medical and electrotherapeutic equipment, optical instruments and equipment, equipment for magnetic and optical researches, as well as production of components (integrated microcircuits, 'active' and 'passive' electronic components ) and spare parts for electronic products,

intelligent robot - an automated device that performs a specific action or remains inactive, taking into account the perceived and recognized external environment ${ }^{8}$.

It follows that the basic concepts, related to the framework on the use of digital technologies, are statutorily formalized, which is quite logical, since digital processes have already penetrated so deeply into the public life that the regulation of these concepts was an objective necessity.

\footnotetext{
${ }^{6}$ Law of the Republic of Kazakhstan of June 25, 2020 No. 347-VI ZRK 'On Amendments to a Number of Legislative Acts of the Republic of Kazakhstan in Connection with Regulation of Digital Technologies'. IS 'Paragraph'.

${ }^{7}$ Law of the Republic of Kazakhstan of November 24, 2015 No. 418-V ZRK 'On Information Technology Development'. IS 'Paragraph'.

${ }^{8}$ Law of the Republic of Kazakhstan of November 24, 2015 No. 418-V 'On Information Technology Development'. Available from: https://online.zakon.kz/Document/?doc_id=33885902\#pos=1[Accessed: 01 May 2021 ].
} 
I. M. Konobeevskaya (2019) believes that both bitcoins and tokens inherently represent the ways of fixing the rights or even claims to certain benefits in a specific decentralized registry. For example, a token can give the right to receive a certain good produced as part of an ICO project, or to receive profit from this project. From that standpoint, it is rather similar to book-entry securities. Actually, the emergence and rapid development of ICO itself is, to a certain extent, a consequence of the rather complicated procedure for IPO.

At the same time, the Law of the Republic of Kazakhstan 'On Information Technology Development' specifies the mode for the turnover of digital assets, see Article 33-1:

'1. The digital asset does not refer to payment facilities.

2. Digital assets can be secured and unsecured.

Secured digital assets include digital tokens and other digital assets that belong to digital facilities of certifying property rights to goods and (or) services issued (provided) by the person who issued the secured digital asset. The types of secured digital assets, as well as the list of rights certified by a digital token, are established by the person issuing the digital token according to the procedure, prescribed by the legislation of the Republic of Kazakhstan.

Unsecured digital assets include digital tokens received as a reward for participating in maintaining consensus in the blockchain according to the procedure prescribed by the legislation of the Republic of Kazakhstan.

3. The issue and turnover of unsecured digital assets within the territory of the Republic of Kazakhstan is prohibited, except for cases specified by the laws of the Republic of Kazakhstan.

4. The digital asset does not provide rights to financial instruments and does not present its owner or proprietary the corresponding rights in relation to the legal entity.

5. The right to the digital asset is certified by recording in the blockchain by a person issuing the digital asset on the distributed data platform, according to the procedure prescribed by the legislation of the Republic of Kazakhstan.

6. Entering the data into the information system about the transfer of the digital asset or the rights to it is allowed, if the following conditions are met:

1) the person who has entered the data is provided with access to the information system of the person issuing the digital asset on the distributed data platform, according to the procedure determined by the authorized body in the field of information security;

2) the information system of the person issuing the digital asset on the distributed data platform meets the requirements established by this law.

7. The owner, proprietary and user, who have access to the information system of the person issuing the digital asset, have equal rights to make changes in accordance with the specified validation algorithm.

In this case, the relevant changes are synchronized for all users of the information system.

8. The person carrying out digital mining becomes the owner of the digital assets that have arisen because of digital mining.

9. The persons carrying out digital mining inform the authorized body in the field of information security about the activities for the implementation of digital mining according to the procedure determined by the authorized body in the field of information security9.

According to the Order of the Minister of Digital Development, Innovations and Aerospace Industry of the Republic of Kazakhstan dated October 29, 2020 No. 407 / NK 'On Approval of the Rules for Issue and Turnover of Secured Digital Assets', the turnover of the secured digital asset is carried out by certifying and transferring rights to secured digital assets, as well as their encumbrance with the rights of third parties, including alienation, acquisition, exchange of digital assets for electronic money, values and other property, by entering the data into the information system, in accordance with the agreement between users of the information system ${ }^{10}$.

In accordance with the Law of the Republic of Kazakhstan 'On Information Technology Development' the digital asset certifies the property rights in the electronic digital form, but the question, whether all

${ }^{9}$ Law of the Republic of Kazakhstan 'On Information Technology Development' of November 24, 2015 No. 418-V. Available from: https://online.zakon.kz/Document/?doc_id=33885902\#pos=1 [Accessed: 01 May 2021].

${ }^{10}$ Order of the Minister of Digital Development, Innovations and Aerospace Industry of the Republic of Kazakhstan of October 29, 2020 No. 407/NK 'On Approval of the Rules for Issue and Turnover of Secured Digital Assets'. IS 'Paragraph'. 
the property rights are certified by a digital asset, remains. Indeed, in the theory of the civil law, property rights are understood as real rights, liability rights, exclusive rights, inheritance rights. Can a digital asset certify, for example, real rights, i.e. the rights to things in tangible form?

In connection with the adoption of the Law of the Republic of Kazakhstan 'On Payments and Payment Systems' dated July 26, 2016 No. 11-VI ZRK ${ }^{11}$, the following concepts were introduced into the legislation of the Republic of Kazakhstan:

electronic money - unconditional and irrevocable monetary obligations of the electronic money issuer stored in the electronic form and accepted as a means of payment in the electronic money system by other system participants,

electronic wallet of electronic money - a method of accounting and storage of electronic money, ensuring their disposal ${ }^{12}$.

It should be noted that the shift away from the material form of some types of property to immaterial one occurred quite a long time ago, which can be confirmed by availability of non-cash money, book-entry securities.

The question of the legal nature of electronic money also does not have an unambiguous opinion in the legal science. The question arises: who is the issuer of electronic money? After all, the right of money introduction to the civil turnover has a public character and belongs exclusively to the state. We consider it quite logical to recognize electronic money as non-cash, i.e., the owner's right of claim against the servicing bank.

The Law of the Republic of Kazakhstan 'On Amendments to a Number of Legislative Acts of the Republic of Kazakhstan in Connection with Technical Regulation, Business Activity, Improvement of State Control System and Payments' dated December 30, 2020 No. 397-VI ZRK provides (see Articles 740, 741 of the Civil Code of the Republic of Kazakhstan) ${ }^{13}$, that it is not allowed to seize, levy execution on electronic money located in electronic wallets of electronic money intended for crediting allowances and social benefits paid from the state budget and (or) the State Social Insurance Fund ${ }^{14}$.

The Russian legal literature may present many works devoted to clarifying the nature of digital rights. For example, L. Yu. Vasilevskaya (2019) points out that the possibility of the substantial existence of new rights only at the digital level indicates the emergence of diverse concepts in the civil legislation in relation to the category of the object of civil rights. The digitalization of the rights does not lead to the emergence of a new type of property rights, which exists along with liability, corporate, exclusive rights, but to their digital method of fixing.

Nevertheless, M. K. Suleymenov (2021) is not alone in his opinion. Russian researchers also adhere to the position that the introduction of the concept of 'digital rights' into legislation is, in principle, terminologically not entirely accurate, and their attribution to the objects of civil rights is completely erroneous. Of course, digital rights can be viewed as a legal fiction. However, the use of legal fiction in legislation should pursue some goal; contribute to the achievement of a certain result. In the case under consideration, the result, apparently, is the extension of the property rights regime to bitcoins and tokens. However, it seems that there is no objective need to create such a complex structure - for regulating the economic turnover, it would be sufficient to recognize the fact that the property rights can be recorded in the digital form, including by making entries into the decentralized registries (Konobeevskaya, 2019).

We should agree with B. M. Gongalo and L. A. Novoselova (2019: 184), who suggest that the creation of a digital image of a particular object of turnover, as a rule, does not change its nature. For example, accounting for shares in the blockchain does not make them a special digital asset. To legalize such accounting, it is enough to make additions to the law on joint stock companies and the law on marketable securities in terms of permissible technologies for accounting for securities.

Thus, the studies of civil scientists lead to one unequivocal conclusion: digital assets, digital rights are a way of fixing property.

\footnotetext{
${ }^{11}$ Law of the Republic of Kazakhstan of July 26, 2016 No. 11-VI ZRK 'On Payments and Payment Systems'. IS 'Paragraph'.

${ }^{12}$ Law of the Republic of Kazakhstan of July 26, 2016 No. 11-VI ZRK 'On Payments and Payment Systems'. IS 'Paragraph'.

${ }^{13}$ Civil Code of the Republic of Kazakhstan of July 1, 1999 No. 409-I (Special Part). Available from: https://online.zakon. kz/Document/?doc_id=1013880\#pos=5665;-57 [Accessed: 01 May 2021].

${ }^{14}$ Law of the Republic of Kazakhstan of December 30, 2020 No. 397-VI ZRK 'On Amendments to a Number of Legislative Acts of the Republic of Kazakhstan in Connection with Technical Regulation, Business Activity, Improvement of State Control System and Payments'. IS 'Paragraph'.
} 


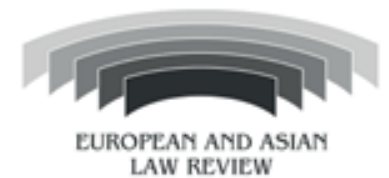

Vol 4. Is. 1

Changes and additions regarding the introduction of digital technologies also affected the forms of protection and were reflected in the Civil Procedural Code of the Republic of Kazakhstan. Indeed, since the introduction of the state of emergency in Kazakhstan ${ }^{15}$, treatment of legal cases was transferred to the video conferencing mode (hereinafter - VC) through various programs: Zoom, WhatsApp, and etc.

The Law of the Republic of Kazakhstan 'On Amendments to a Number of Legislative Acts of the Republic of Kazakhstan in Connection with Enhancing Protection of Property Rights, Arbitration Proceedings, Caseload Optimization and Further Humanization of Criminal Legislation' dated January 21, 2019 No. 217-VI ZRK introduced a norm to be fixed in Article 252 of the Civil Procedural Code of the Republic of Kazakhstan concerning sanctioning judicial custodian's decrees by certifying them with the electronic digital signature of the judge or the prosecutor ${ }^{16}$.

By the Law of the Republic of Kazakhstan 'On Amendments to a Number of Legislative Acts of the Republic of Kazakhstan in Connection with Business Environment Development and Regulations of Trading Activity' dated April 2, 2019 No. 241-VI ZRK (hereinafter - the Law of the Republic of Kazakhstan dated April 2, 2019) the Civil Procedural Code of the Republic of Kazakhstan (hereinafter - the Civil Procedural Code of the Republic of Kazakhstan) was added with Chapter 11-1 of the following content:

'Chapter 11-1. Features of e-judicial proceedings

Article 133-1. Format of civil judicial proceedings

1. Civil judicial proceedings are conducted in the paper or electronic format, depending on the method of reference to the court chosen by the party presenting a claim.

2. The court, considering the views of the parties and the technical facilities for conducting the process, can change the format of the proceedings by a reasoned ruling.

3. If the judicial proceedings are conducted in the electronic format, an electronic civil case is formed.

At this, the original of the judicial act is an electronic judicial act posted into the automated information system of the court.

4. When the format of the proceedings is changed, the case materials are converted into the appropriate format and certified by the judge.

Article 133-2 the RK Civil Procedural Code enshrined the concept and mode of electronic documents:

'1. Procedural acts and actions of the court, persons participating in the case, can be executed in the form of an electronic document certified by an electronic digital signature. These documents are equivalent to documents in writing, except for cases when the legislation of the Republic of Kazakhstan does not allow the use of an electronic document.

2. The technical requirements for the electronic document and the procedure for its handling in the automated information system of the court are determined by the body that provides organizational and material support for the activities of the courts, taking into account the requirements of the legislation of the Republic of Kazakhstan' ${ }^{17}$.

Article 133-3 the RK Civil Procedural Code specifies the provisions for participation in the judicial process by using technical means of communication.

Access to justice is closely related to the ability to obtain qualified legal assistance by a person applying to the court. Submission of documents to the court in the electronic form, obtaining judicial acts and information on the progress of the case through the court's website on the Internet make the communication of the court for the parties involved operational, efficient and low-cost (Prizhennikova \& Kolyada, 2020: 241).

It should be noted that the RK Law dated April 2, 2019 amended Article 416 of the RK Civil Procedural Code by adding parts three and four of the following content:

'3. The appellate court shall conduct the proceedings in the electronic format, if this format was used in the court of the first instance.

\footnotetext{
${ }^{15}$ Decree of the President of the Republic of Kazakhstan of March 15, 2020 No. 285 'On Introduction of the State of Emergency in the Republic of Kazakhstan' Available from: https://online.zakon.kz/Document/?doc_id=32648341\#pos=8 [Accessed: 01 May 2021].

${ }^{16}$ Law of the Republic of Kazakhstan of January 21, 2019 No. 217-VI ZRK 'On Amendments to a Number of Legislative Acts of the Republic of Kazakhstan in Connection with Enhancing Protection of Property Rights, Arbitration Proceedings, Caseload Optimization and Further Humanization of Criminal Legislation'. IS 'Paragraph'.

${ }^{17}$ Civil Procedural Code of the Republic of Kazakhstan of October 31, 2015 No. 377-V ZRK. Available from: //https:// online.zakon.kz/Document /?doc_id=34329053\#pos=1 [Accessed: 01 May 2021].
} 
4. If it is impossible to use the electronic format, the appellate court switches to the paper format by formulating the relevant reasoned ruling ${ }^{18}$.

By the Law of the Republic of Kazakhstan 'On Amendments to Civil Procedural Code of the Republic of Kazakhstan in Connection with Introducing of Contemporary Formats into Court Activities, Reduction of Excessive Legal Proceedings and Costs' dated June 10, 2020 No. 342-VI ZRK (hereinafter- the Law dated June 10, 2020) the Civil Procedural Code of the Republic of Kazakhstan was added with Article 133-4 of the following content:

'Article 133-4. Electronic record

1. The audio, video taping of the trial shall be recognized as the electronic record of the trial.

2. The technical requirements to the electronic record, ensuring completeness, structuring and highquality reproduction, are determined by the body that provides organizational and material support for the activities of the courts, taking into account the requirements of this Code' ${ }^{19}$.

The Law of the Republic of Kazakhstan dated June 10, 2020 specifies the issuance of a court order in the electronic form for the writ proceedings in accordance with Article 134 of the Civil Procedural Cod of the Republic of Kazakhstan; paragraph 5 of Article 146 of the Civil Procedural Code of the Republic of Kazakhstan denotes that the court shall consider the case by application of the simplified (written) proceedings in the electronic format without presence of the parties involved.

The Law of the Republic of Kazakhstan dated June 10, 2020 enshrines the status of electronic documents as independent evidence and clearly separates the use of written evidence and evidence in the form of electronic documents in Article 100 of the Civil Procedural Code of the Republic of Kazakhstan ${ }^{20}$.

The Law of the Republic of Kazakhstan 'On Amendments to a Number of Legislative Acts of the Republic of Kazakhstan in Connection with Improvement of Business Climate' dated June 29, 2020 No. 352-VI ZRK (hereinafter - the RK Law dated June 29, 2020) enshrines in the Civil Procedural Code of the Republic of Kazakhstan the priority of the electronic notification. Namely, paragraph 2 of Article 2 of the Civil Procedural Code of the Republic of Kazakhstan denotes that in the case of absence of information about the e-mail address or subscriber number of cellular communication, or other electronic means of communication that ensure the fixation of the notification or warning to appear in court for the party involved into the trial, a subpoena or other written citation is sent to the last known place of residence or location of such party.

The RK Law dated June 29, 2020 also separates the use of summons in the electronic form and on hard copies, in particular in Articles 127, 130, 131 of the Civil Procedural Code of the Republic of Kazakhstan ${ }^{21}$.

It seems important to pay attention to the fact that the digitalization is a modern component of the process of administering justice, as well as of any other sphere of the governmental and other services. The introduction of contemporary technologies will significantly reduce and simplify the path to the judicial protection. In other words, we are talking about the optimization of judicial control to protect the constitutional rights of citizens, including the access to justice. Creation and development of the unified information space for the judicial system ensures openness, accessibility of information on the activities of courts, presented in the digital form; efficiency and quality of information and analytical support of legal proceedings, quality of collection and execution of court documents, acquisition and logical processing of court statistics, quality of resource and legal support for activities of courts, etc. (Prizhennikova \& Kolyada, 2020: 241)

The innovations massively introduced in the Republic of Kazakhstan only in 2020 are far from the most advanced experience.

${ }^{18}$ Law of the Republic of Kazakhstan of April 2, 2019 No. 241-VI ZRK 'On Amendments to a Number of Legislative Acts of the Republic of Kazakhstan in Connection with Business Environment Development and Regulations of Trading Activity'. IS 'Paragraph'.

${ }^{19}$ Civil Procedural Code of the Republic of Kazakhstan of October 31, 2015 No. 377-V ZRK. Available from: //https:// online.zakon.kz/Document/?doc_id=34329053\#pos=1 [Accessed: 01 May 2021].

${ }^{20}$ Law of the Republic of Kazakhstan of June 10, 2020 No. 342-VI ZRK 'On Amendments to Civil Procedural Code of the Republic of Kazakhstan in Connection with Introducing of Contemporary Formats into Court Activities, Reduction of Excessive Legal Proceedings and Costs'. IS 'Paragraph'.

${ }^{21}$ Law of the Republic of Kazakhstan of June 29, 2020 No. 352-VI ZRK 'On Amendments to a Number of Legislative Acts of the Republic of Kazakhstan in Connection with Improvement of Business Climate'. IS 'Paragraph'. 
The experience of Singapore, where the form of digital justice was introduced already in 1995, seems to be interesting (Kupchina, 2020: 95).

The introduction of the state of emergency in Kazakhstan in March of $2020^{22}$ led to a massive transition to remote work, which made it necessary to adapt the norms of the Labour Code of the Republic of Kazakhstan to the circumstances.

The Law of the Republic of Kazakhstan 'On Amendments to a Number of Legislative Acts of the Republic of Kazakhstan in Connection with Labour' dated May 4, 2020 No. 321-VI ZRK (hereinafter the RK Law dated May 4, 2020) introduced an amendment to subparagraph 27 of paragraph 2 of Article 23 of the Labour Code of the Republic of Kazakhstan ${ }^{23}$ concerning the obligation of the employer to enter data on the conclusion and termination of the employment contract with the employee, changes and (or) additions submitted to this contract into the uniform system of employment contracts accounting. The RK Law dated May 4, 2020 introduced to Article 1 of the Labour Code of the Republic of Kazakhstan the concept of the uniform system of employment contracts accounting - the information system designed for automated accounting of employment contracts, employment activities and number of employees. Thus, on the 4th of May 2020 within the territory of Kazakhstan there was implemented the uniform electronic data base of employment contracts in accordance with the Order of the Minister of Labour and Social Protection of the Republic of Kazakhstan dated September 3, 2020 No. 353 'On Approval of the Rules for Submission and Obtaining Information on an Employment Contract in the Uniform System of Employment Contracts Accounting, ${ }^{24}$.

The RK Law dated May 4, 2020 amended Article 11 of the Labour Code of the Republic of Kazakhstan by adding part two of the following content: 'The employer's acts are drawn up in writing or in the form of an electronic document certified by means of an electronic digital signature ${ }^{25}$. This way the electronic document exchange for the employer's acts was introduced.

\section{Conclusion}

Of course, the need to ensure legal regulation in the new conditions is dictated by global challenges, but it also leads to transparency and real publicity of information; we can only hope that in these conditions the right of a person and a citizen to information, to provision of its confidentiality and non-disclosure will remain secure.

At this stage of development of the civil law, the opinion of the majority of civil law experts comes down to the fact that digital assets, digital rights are not by their nature a new type of property, property right, and so far, except the fact that the digital form represents only a way of fixing the property, no any different nature of these institutions is not seen.

As for the justice itself: the digitalization of the system for ensuring the protection of human and civil rights led to the fact that access to justice had made a significant step towards development, this is fully consistent with the generally recognized principles of publicity, transparency and openness of the legal proceedings. In other words, there are much more positive aspects in this process: avoiding document exchange, saving time, simplified search for court cases, notifying the parties involved using various communication methods, which makes it possible to speed up the communication process, unlike postal service providers.

Such qualitative changes relate not only to the justice, but also to deals in electronic form, for example, introduction of electronic databases for compulsory insurance has led to a legal effect expressed itself in

\footnotetext{
${ }^{22}$ Decree of the President of the Republic of Kazakhstan of March 15, 2020 No. 285 'On Introduction of the State of Emergency in the Republic of Kazakhstan'. Available from: https://online.zakon.kz/Document/?doc_id=32648341\#pos=8 [Accessed: 01 May 2021].

${ }^{23}$ Labour Law of the Republic of Kazakhstan of November 23, 2015 No. 414-V ZRK. Available from: https://online.zakon. kz/Document/?doc_id=38910832\#pos=549;8 [Accessed: 01 May 2021].

${ }^{24}$ Order of the Minister of Labour and Social Protection of the Republic of Kazakhstan of September 3, 2020 No. 353 'On Approval of the Rules for Submission and Obtaining Information on an Employment Contract in the Uniform System of Employment Contracts Accounting'. IS 'Paragraph'.

${ }^{25}$ Law of the Republic of Kazakhstan of May 4, 2020 No. 321-VI ZRK 'On Amendments to a Number of Legislative Acts of the Republic of Kazakhstan in Connection with Labour'. IS 'Paragraph'.
} 
prevention of forgery and falsification of documents due to the replacement of hard copies with electronic ones.

\section{References}

Gongalo, B. M. \& Novoselova, L.A. (2019) Do Digital Rights Carve Out a Niche in the System of Objects of Civil Law? Perm Juridical Almanac. (2), 179-192. (in Russian).

Konobeevskaya, I. M. (2019) Digital Rights As a New Object of Civil Rights. Izv. Saratov Univ. (N. S.), Ser. Economics. Management. Law. 19 (3), 330-334. https://doi.org/10.18500/1994-2540-2019-193-330-334. (in Russian).

Kupchina, E. V. (2020) Digital Justice in Countries of the Asia-Pacific Region: Experience of Singapore. Mezhdunarodnoi nauchno-prakticheskoi konferentsii 'Innovatsionnye aspekty razvitiya nauki i tekhniki' [Digest of International Research-to-Practice Conference 'Innovation Aspects of Development of Science and Technology']. Saratov, Individual'nyi predprinimatel' N.V. Emel'yanov, 92-98. (in Russian).

Prizhennikova, A. N. \& Kolyada, G. Yu. (2020) Digitalization of Justice: Theoretical and Practical Aspects. Education and Law. (2), 240-250. https://doi.org/10.24411/2076-1503-2020-10243. (in Russian).

Suleymenov M. K. (2021) Tsifrovizatsiya $i$ sovershenstvovanie grazhdanskogo zakonodatel'stva [Digitalization and Improvement of Civil Legislation]. Available from: //https://online.zakon.kz/ Document/?doc_id=39845707\#pos=5;-106 [Accessed: 01 May 2021]. (in Russian).

Vasilevskaya, L. Yu. (2019) Token As a New Object of Civil Rights: Problems of Digital Right Legal Qualification. Available from: https://urfac.ru/?p=2398 [Accessed: 01 May 2021]. (in Russian).

\section{Information about the author}

Aizhan A. Amangeldy - Doctor of Juridical Sciences, Professor of the Department of Civil Legal Disciplines, Euroasian Law Academy of D. A. Kunaev (Almaty, Republic of Kazakhstan, e-mail: aizhan amangeldy@mail.ru).

(C) A. A. Amangeldy, 2021

Date of Paper Receipt: May 10, 2021

Date of Paper Approval: June 25, 2021

Date of Paper Acceptance for Publishing: July 26, 2021 